\title{
FAKTOR-FAKTOR YANG MEMPENGARUHI PRODUKTIVITAS TENAGA KERJA INDUSTRI KECILKOTA PALOPO
}

\author{
Oleh: Imran Ukkas \\ imranukkas@stiem.ac.id \\ Program Studi Manajemen Sekolah Tinggi Ilmu Ekonomi Muhammadiyah Palopo
}

\begin{abstract}
Abstrak
Kualitas produksi yang dihasilkan oleh industri kecil sangat ditentukan oleh produktivitas tenaga kerjanya. Tingkat produktivitas tenaga kerja yang cenderung rendah dapat mengakibatkan menurunnya jumlah produksi. Hal ini dapat disebabkan oleh beberapa faktor antara lain tingkat pendidikan, usia, pengalaman kerja, dan jenis kelamin. Penelitian ini bertujuan untuk mengetahui seberapa besar pengaruh tingkat pendidikan, usia, pengalaman kerja, dan jenis kelamin terhadap produktivitas tenaga kerja pada industri kecil di Kota Palopo. Sampel penelitian sebanyak 100 orang tenaga kerja pada industri kecil yang ada di Kota Palopo yang diambil dengan menggunakan teknik probability random sampling. Adapun metode analisis dalam penelitian yaitu menggunakan analisis kuantitatif dengan rumus regresi linear berganda. Hasil penelitian menunjukkan bahwa tingkat pendidikan, usia, pengalaman kerja dan jenis kelamin berpengaruh positif signifikan terhadap produktivitas tenaga kerja industri kecil Kota Palopo. Selanjutnya dari keempat variabel independen tersebut yang memiliki pengaruh dominan terhadap produktivitas tenaga kerja yaitu variabel usia sebesar 2,331. Hasil penelitian ini diharapkan dapat menjadi bahan pengembangan kajian ilmu manajemen sumber daya manusia terkhusus mengenai produktivitas tenaga kerja dalam rangka upaya peningkatan produksi pada industri kecil.
\end{abstract}

Kata Kunci: Tingkat Pendidikan, Usia, Pengalaman Kerja, Jenis Kelamin, Produktivitas Tenaga Kerja, Industri Kecil.

\section{A. PENDAHULUAN}

Pertumbuhan ekonomi di suatu daerah salah satunya ditentukan oleh perkembangan pada sektor industri. Olehnya itu banyak daerah di Indonesia yang menitikberatkan kekuatan ekonominya pada sektor indutsri, terkhusus pada industri kecil. Industri kecil cenderung lebih mudah berkembang disebabkan karena tidak membutuhkan modal yang terlalu besar, teknologi yang digunakan juga relatif sederhana, dan bahan bakunya pun mudah didapatkan. Industri kecil mempunyai peranan yang sangat penting dan strategis bagi perekonomiansuatu daerah, karena keberadaannya banyak memberikan manfaat dalam pengembangan ekonomi daerah. 
Kota Palopo merupakan salah satu kota yang memiliki jumlah industri kecil cukup banyak dan setiap tahunnya cenderung mengalami penambahan. Namun pada kenyataannya, banyaknya jumlah industri kecil tidak berbanding lurus dengan nilai produksi yang dihasilkan yang masih dalam kategori rendah. Secara umum yang menjadi permasalahan utama dari rendahnya hasil produksi pada industri kecil adalah rendahnya produktivitas tenaga kerja yang disebabkan oleh kurangnya kualitas sumber daya manusia. Wartana (2011) mengemukakan bahwa peranan sumber daya manusia sangat penting dalam pencapaian tujuan organisasi karena sumber daya manusia merupakan ujung tombak dalam suatu organisasi.

Produktivitas secara sederhana dapat diartikan dengan peningkatan kuantitas dan kualitas. Menurut Utami (2015) produktivitas tenaga kerja dapat dipengaruhi oleh beberapa faktor seperti umur, tingkat pendidikan formal, pengalaman bekerja, upah, dan curahan tenaga kerja.Terdapat beberapa faktor yang dapat mempengaruhi produktivitas tenaga kerja antara lain tingkat pendidikan, usia, pengalaman kerja, dan jenis kelamin.

Angkatan kerja Indonesia selainjumlah yang besar juga rata-ratamemiliki tingkat pendidikan yangrendah.Jika tingkat pendidikan pekerja berkolerasi positif denganketerampilan dan produktivitas,kondisi ini menunjukkan sebagianbesar tenaga kerja Indonesiamerupakan pekerja yang memilikiketerampilan yang rendah (Suyono dan Hermawan, 2013).Tingkat pendidikan sangat dibutuhkan untuk membentuk sumber daya manusia yang berkualitas sebab dengan pendidikan dapat menciptakan pola pikir tenaga kerja sehingga mampu untuk bersaing dalam dunia kerja. Semakin tinggi pendidikan seorang pekerja maka pengetahuan dan wawasannya pun semakin luas, dapat berpikir lebih terarah, sehingga pada akhirnya produktivitasnya juga cenderung semakin tinggi.

Produktivitas tenaga kerja merupakan barometer seberapa jauh pekerja dipergunakan dengan efektif dalam suatu proses produksi untuk mencapai output yang diharapkan. Salah satu unsur penunjangnya yaitu tingkat usia tenaga kerja. Pekerja dengan tingkat usia produktif yaitu 15-50 tahun dapat beradaptasi dengan cepat dengan tugas yang baru serta mudah memahami dan menggunakan teknologi. Namun lain halnya dengan pekerja usia non produktif, di mana kemampuan fisik yang tentunya semakin berkurang dan sulit beradaptasi dengan teknologi, sehingga produktivitas kerjanya pun akan menurun.

Di samping faktor tingkat usia, pengalaman kerja juga dapat mempengaruhi produktivitas tenaga kerja. Umur karyawan mempunyai pengaruh terhadap kemampuan untuk bekerja (Utami, 2015). Dengan adanya pengalaman kerja yang memadai, maka dapat menunjukkan tingkat penguasaan tenaga kerja dalam menyelesaikan suatu pekerjaan sehingga dapat dikatakan menjadi ahli atau spesialisasi pada bidangnya masing-masing. Berbeda dengan pekerja yang kurang pengalaman kerja, akan sulit untuk beradaptasi dengan suasana kerja yang baru, kemudian cenderung kaku dalam menyelesaikan pekerjaan. 
Selain ketiga faktor di atas, jenis kelamin juga merupakan faktor penting yang menentukan produktivitas kerja. Pada umumnya tingkat produktivitas pekerja laki-laki cenderung lebih tinggi dibanding dengan pekerja wanita. Penyebabnya antara lain bahwa laki-laki memiliki kekuatan fisik yang lebih besar daripada wanita, yang di mana tenaga kerja industri kecil lebih banyak mengandalkan kekuatan fisik. Selain itu, wanita yang sudah berkeluarga cenderung lebih sulit untuk membagi waktunya untuk bekerja karena sebagian besar waktunya digunakan untuk mengurus rumah tangga.

Keempat faktor inilah yang diduga berpengaruh terhadap rendahnya produktivitas tenaga kerja pada industri kecil di Kota Palopo, sehingga menarik bagi peneliti untuk melakukan penelitian yang berkaitan dengan produktivitas tenaga kerja industri kecil.

\section{B. TINJAUAN TEORITIS}

\section{Pengaruh Tingkat Pendidikan terhadap Produktivitas Kerja}

Pendidikan yang lebih tinggi mengakibatkan produktivitas kerja yang lebih tinggi dan oleh sebab itu memungkinkan penghasilan yang lebih tinggi juga. Pendidikan merupakan salah satu faktor penting dalam pengembangan sumber daya manusia.

Penelitian Suyono dan Hermawan (2013) menyatakan terdapat pengaruh pendidikan tenaga kerja terhadap produktivitas tenaga kerja. Hal ini menunjukkan bahwa semakin tinggi tingkat pendidikan seseorang maka akan semakin tinggi produktivitas kerjanya sebab orang tersebut akan memiliki wawasan dan pengetahuan yang lebih luas. Begitu pun sebaliknya, jika pendidikan seseorang rendah maka wawasan dan pengetahuannya juga akan rendah sehingga akan berdampak kepada menurunnya produkstivitas kerja. Pendidikan tidak hanya akan menambah wawasan dan pengetahuan tetapi juga dapat meningkatkan keterampilan kerja sehingga akan meningkatkan produktivitas kerja.

Hal ini juga sejalan dengan studi Hasanah dan Widowati (2011) yang menemukan adanya pengaruh tingkat pendidikan terhadap produktivitas tenaga kerja. Pendidikan memberikan pengetahuan untuk penyelesaian pekerjaan. Semakin tinggi tingkat pendidikan maka semakin tinggi pula tingkat produktivitas tenaga kerja. Sebaliknya, semakin rendah tingkat pendidikan maka semakin rendah pula tingkat produktivitas tenaga kerja.

H1 : Tingkat pendidikan berpengaruh terhadap produktivitas tenaga kerja industri kecil

\section{Pengaruh Usia terhadap Produktivitas Kerja}

Tingkat usia sangatlah berpengaruh terhadap produktivitas tenaga kerja sebab terkait dengan kemampuan fisik seorang tenaga kerja. Pekerja yang berada pada usia produktif cenderung lebih kuat dari segi fisik dibanding pekerja usia non produktif. Semakin 
tinggi usia tenaga kerja maka produktivitas kerja akan semakin menurun. Tenaga kerja yang memiliki usia lebih tua cenderung memiliki produktivitas yang rendah. Hal ini disebabkan karena pada usia tua kekuatan atau tenaga fisik akan cenderung menurun.

Hasanah dan Widowati (2011) mengemukakan adanya pengaruh usia tenaga kerja terhadap produktivitas tenaga kerja. Usia muda mencerminkan fisik yang kuat sehingga mampu bekerja cepat sehingga output yang dihasilkan juga meningkat, dan sebaliknya. Umur sangat berpengaruh terhadap kemampuan fisik tenaga kerja. Usia muda, produksi yang dihasilkan besar. Usia tua produktivitasnya menurun.

Umur tenaga kerja yang berada dalam usia produktif (15-60 tahun) memiliki berhubungan positif dengan produktivitas tenaga kerja. Artinya jika umur tenaga kerja pada kategori produktif maka produktivitas kerjanya akan meningkat. Ini dikarenakan pada tingkat usia produktif tenaga kerja memiliki kreatifitas yang tinggi terhadap pekerjaan sebab didukung oleh pengetahuan dan wawasan yang lebih baik serta mempunyai tanggung jawab yang tinggi terhadap tugas yang diberikan. (Suyono dan Hermawan, 2013).

H2 : Usia berpengaruh terhadap produktivitas tenaga kerja industri kecil

\section{Pengaruh Pengalaman Kerja terhadap Produktivitas Kerja}

Pengalaman kerja seseorang menunjukkan jenis-jenis pekerjaan yang pernah dilakukan seseorang dan memberikan peluang yang besar bagi seseorang untuk melakukan pekerjaan yang lebih baik. Semakin luas pengalaman kerja seseorang, semakin terampil melakukan pekerjaan dan semakin sempurna pola berpikir sikap dalam bertindak untuk mencapai tujuan yang telah ditetapkan (Puspaningsih, 2014).

Pengalaman merupakan proses pembelajaran dan pertambahan perkembangan potensi bertingkah laku baik dari pendidikan formal maupun non-formal atau bisa diartikan sebagai suatu proses yang membawa seseorang kepada suatu pola tingkah laku yang lebih tinggi. Pengalaman kerja tercermin dari pekerja yang memiliki kemampuan bekerja pada tempat lain sebelumnya. Semakin banyak pengalaman yang didapatkan oleh seorang pekerja akan membuat pekerja semakin terlatih dan terampil dalam melaksanakan pekerjaannya (Amron, 2009). Adanya tenaga kerja yang memiliki pengalaman kerja diharapkan memperolehpekerjaan sesuai dengan keahliannya. Semakin lama seseorang dalam pekerjaan yang sesuai dengan keahliannya maka diharapkan akan mampu meningkatkan produktivitasnya. Maka dapat dikatakan bahwa pengalaman kerja memiliki pengaruh positif terhadap produktivitas tenaga kerja.

Hasanah dan Widowati (2011) menemukan adanya pengaruh yang signifikan antara pengalaman bekerja dengan tingkat produktivitas tenaga kerja. Pengalaman kerja membuatpekerja lebih tekun, telaten dan berkualitas. Berkaitan juga dengan latihan kerja dan keterampilan dalam menggunakan alat kerja.

Semakin lama seorang pekerja melakukan pekerjaannya, maka akan semakin terampil. Keterampilan yang tinggi akan berdampak positif terhadap kinerjanya, seperti 
waktu yang diperlukan untuk menyelesaikan pekerjaannya menjadi semakin cepat, selain itu kualitas hasil pekerjaannya juga akan semakin baik (Sulaeman, 2014). Pengalaman kerja mempunyai pengaruh terhadap banyaknya produksi dan besar kecilnya efisiensi yang dapat dilihat dari hasil produksi tenaga kerja yang diarahkan. Dalam pengertian lain, pengalaman kerja juga dapat diperoleh dengan melewati masa kerja yang telah dilakukan di suatu tempat kerja. Pengalaman kerja seseorang dalam suatu pekerjaan yang dimanifestasikan dalam jumlah masa kerja akan meningkatkan kemampuan dan kecakapan kerja seseorang sehingga hasil kerja akan semakin meningkat.

$\mathrm{H} 3$ : pengalaman kerja berpengaruh terhadap produktivitas tenaga kerja industri kecil

\section{Pengaruh Jenis Kelamin terhadap Produktivitas Kerja}

Adanya perbedaan jenis kelamin dapat mempengaruhi tingkat produktivitas seseorang. Secara universal, tingkat produktivitas laki-laki lebih tinggi dari perempuan. Hal tersebut dipengaruhi oleh faktor-faktor yang dimiliki oleh perempuan seperti fisik yang kurang kuat, dalam bekerja cenderung menggunakan perasaan atau faktor biologis seperti harus cuti ketika melahirkan (Amron, 2009). Faktor jenis kelamin ikut menentukan tingkat partsipasi dan produktivitas seseorang dalam bekerja. Tenaga kerja pada dasarnya tidak dapat dibedakan berdasarkan pada jenis kelamin. Tetapi pada umumnya laki-laki akan lebih produktif untuk pekerjaan yang mengandalkan kekuatan fisik.

Variabel jenis kelamin memilki pengaruh positif dan signifikan terhadap produktivitas tenaga kerja. Pada pekerja dengan jenis kelamin pria umumnya tingkat produktivitas lebih banyak dibandingkan dengan wanita (Hasanah dan Widowati, 2011). Hal ini sejalan dengan tingkat partisipasi kerja laki-laki selalu lebih tinggi dari tingkat partisipasi kerja perempuan karena laki-laki dianggap pencari nafkah yang utama bagi keluarga, sehingga pekerja laki-laki biasanya lebih selektif dalam memilih pekerjaan yang sesuai dengan aspirasinya baik dari segi pendapatan maupun kedudukan dibanding pekerja perempuan. Hampir semua laki-laki yang telah mencapai usia kerja terlibat dalam kegiatan ekonomi karena laki-laki merupakan pencari nafkah utama dalam keluarga.

$\mathrm{H} 4$ : jenis kelamin berpengaruh terhadap produktivitas tenaga kerja industri kecil 


\section{Kerangka Konseptual}



\section{METODE PENELITIAN}

Penelitian ini merupakan jenis penelitian Explanatory Research yang bertujuan untuk mengkaji dan menganalisis pengaruh antara variabel independen terhadap variabel dependen melalui pengujian hipotesis. Adapun data yang digunakan yaitu data primer yang dikumpulkan melalui metode kuisioner. Adapun responden penelitian merupakan tenaga kerja industri kecil yang ada di Kota Palopo sejumlah 100 orang yang dipilih dengan menggunakan teknik probability random sampling. Oleh karena sampel diambil secara acak maka berikut ini tabel distribusi responden berdasarkan kecamatan:

Tabel 1. Distribusi Responden

\begin{tabular}{cccc}
\hline \multirow{2}{*}{ Kecamatan } & \multicolumn{2}{c}{ Jumlah responden } & \multirow{2}{*}{ Jumlah } \\
\cline { 2 - 3 } & Pria & Wanita & \\
\hline Wara & 19 & 11 & 30 \\
\hline Wara Timur & 11 & 4 & 15 \\
\hline Wara Selatan & 6 & 3 & 9 \\
\hline Wara Utara & 8 & 6 & 14 \\
\hline Bara & 14 & 12 & 26 \\
\hline Mungkajang & 4 & 2 & 6 \\
\hline Total & 62 & 38 & 100 \\
\hline
\end{tabular}

Analisis data dalam penelitian ini menggunakan analisis statistik deskriptifdan analisis regresi linear berganda. Analisis statistik deskriptif digunakan untuk menganalisa data dengan cara mendeskripsikan atau menggambarkan data yang telah terkumpul sebagaimana adanya tanpa bermaksud membuat kesimpulan yang berlaku untuk umum atau generalisasi. Kemudian analisis regresi linear berganda dilakukan untuk menjelaskan pengaruh variabel independen terhadap variabel dependen. 


\section{ANALISIS DAN PEMBAHASAN}

Tabel 2. Tingkat Pendidikan Responden Deskripsi Responden berdasarkan Tingkat Pendidikan

\begin{tabular}{ccc}
\hline Tingkat Pendidikan & Frekuensi & Persentase (\%) \\
\hline SD & 19 & 19 \\
\hline SMP & 25 & 25 \\
\hline SMA/SMK & 45 & 45 \\
\hline D1-D3 & 3 & 3 \\
\hline S1 & 8 & 8 \\
\hline Jumlah & 100 & 100
\end{tabular}

Berdasarkan data tersebut, dapat disimpulkan bahwa dari segi pendidikan, tenaga kerja industri kecil Kota Palopo dikategorikan cukup. Hal ini ditunjukkan oleh dominan responden berpendidikan SMA/SMK yaitu sebanyak 45 orang. Tingkat pendidikan yang tinggi dapat menunjang pengetahuan, wawasan, dan keterampilan sehingga hal ini dapat mempengaruhi tingkat produktivitas tenaga kerja.

Tabel 3. Usia Responden Deskripsi Responden berdasarkan Usia

\begin{tabular}{ccc}
\hline Usia & Frekuensi & Persentase $(\%)$ \\
\hline$<15$ tahun & 7 & 7 \\
\hline $15-64$ tahun & 89 & 89 \\
\hline$>64$ tahun & 4 & 4 \\
\hline Total & 100 & 100
\end{tabular}

Responden terbanyak memiliki usia 15-64 tahun atau dalam kategori usia produktif yaitu sebanyak 89 orang. Hal ini menunjukkan bahwa tenaga kerja industri kecil Kota Palopo berada pada kondisi yang optimal dalam menciptakan produktivitas yang tinggi.

Tabel 4. Pengalaman Kerja Responden Deskripsi Responden berdasarkan Pengalaman Kerja

\begin{tabular}{ccc}
\hline Pengalaman Kerja & Frekuensi & Persentase (\%) \\
\hline$<1$ tahun & 37 & 37 \\
\hline $1-5$ tahun & 41 & 41 \\
\hline $6-10$ tahun & 11 & 11 \\
\hline $11-15$ tahun & 8 & 8 \\
\hline$>15$ tahun & 3 & 3 \\
\hline Total & 100 & 100 \\
\hline
\end{tabular}


Dari hasil di atas, dapat dilihat bahwa tenaga kerja industri kecil paling banyak mempunyai pengalaman kerja antara 1-5 tahun yaitu sebanyak 41 orang, sedangkan paling sedikit berpengalaman kerja $>15$ tahun yaitu sebanyak 3 orang. Hal ini menunjukkan bahwa pengalaman kerja yang dimiliki oleh tenaga kerja industri kecil masih perlu ditingkatkan untuk mencapai produktivitas yang maksimal.

Tabel 5. Jenis Kelamin Responden Deskripsi Responden berdasarkan Jenis Kelamin

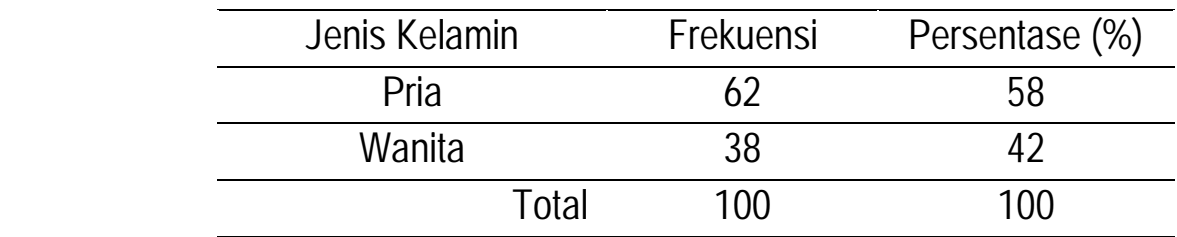

\section{Uji Validitas}

Untuk mengetahui apakah item-item pernyataan yang terdapat dalam kuisioner benar-benar mengukur konsep yang dimaksudkan dalam penelitian dengan tepat (valid), maka dilakukan uji validitas. Setiap item pernyataan dikatakan valid jika koefisien korelasi $(r) \geq 0,5$. Adapun hasil uji validitas dari instrumen kuisioner yang telah dilakukan dapat dilihat dalam tabel berikut:

\section{Tabel 6. Uji Validitas}

\begin{tabular}{lcc}
\multicolumn{1}{c}{ Item Pernyataan } & $\begin{array}{c}\text { Koefisien } \\
\text { korelasi }\end{array}$ & Keterangan \\
\hline $\begin{array}{l}\text { Pekerjaan yang Anda lakukan saat ini sudah sesuai dengan bidang } \\
\text { Pendidikan Anda }\end{array}$ & 0,762 & Valid \\
\hline $\begin{array}{l}\text { Pengetahuan yang Anda dapatkan selama menempuh pendidikan } \\
\text { sangat bermanfaat untuk diterapkan dalam pekerjaan Anda }\end{array}$ & 0,539 & Valid \\
\hline $\begin{array}{l}\text { Pendidikan yang Anda miliki saat ini dapat meningkatkan } \\
\text { pengetahuan dan keterampilan kerja }\end{array}$ & 0,500 & Valid \\
\hline $\begin{array}{l}\text { Pekerjaan Anda sangat ditunjang oleh Pendidikan yang Anda miliki } \\
\text { Saat ini Anda berada pada usia produktif tenaga kerja }\end{array}$ & 0,518 & Valid \\
\hline $\begin{array}{l}\text { Kreatifitas Kerja yang Anda miliki semakin meningkat seiring dengan } \\
\text { bertambahnya usia Anda }\end{array}$ & 0,531 & Valid \\
\hline $\begin{array}{l}\text { Pengetahuan dan Wawasan yang Anda miliki semakin bertambah } \\
\text { seiring dengan bertambahnya usia Anda }\end{array}$ & 0,555 & Valid \\
\hline $\begin{array}{l}\text { Pada usia sekarang, Anda mampu menyelesaikan pekerjaan Anda } \\
\text { dengan baik. }\end{array}$ & 0,606 & Valid \\
\hline Anda mempunyai pengalaman kerja yang baik saat ini & 0,804 & Valid \\
\hline $\begin{array}{l}\text { Anda dapat menyelesaikan pekerjaan dengan mudah berkat } \\
\text { pengalaman kerja yang Anda miliki saat ini }\end{array}$ & 0,526 & Valid \\
\hline $\begin{array}{l}\text { Pengalaman kerja membuat Anda lebih tekun dan telaten dalam } \\
\text { menyelesaikan pekerjaan. }\end{array}$ & 0,600 & Valid \\
\hline Kesalahan kerja dapat dihindari berkat pengalaman kerja yang Anda & 0,746 & Valid \\
\hline
\end{tabular}




\begin{tabular}{lcc}
\hline miliki & & \\
\hline Pekerja pria lebih produktif dibanding pekerja wanita & 0,631 & Valid \\
\hline Pekerja pria lebih kuat dari segi fisik dibanding pekerja wanita & 0,532 & Valid \\
\hline $\begin{array}{l}\text { Tingkat } \\
\text { wanita }\end{array}$ & 0,510 & Valis \\
\hline Pekerja wanita lebih ulet dan cekatan dibanding pekerja pria & 0,535 & Valid \\
\hline $\begin{array}{l}\text { Pekerjaan yang saya lakukan sudah sesuai dengan standar kerja } \\
\text { yang ditetapkan }\end{array}$ & 0,514 & Valid \\
\hline Pekerjaan yang saya selesaikan sesuai dengan target yang ditetapkan & 0,540 & Valid \\
\hline Saya mampu menyelesaikan pekerjaan dengan tepat waktu & 0,690 & Valid \\
\hline Saya mampu bekerjasama dengan pekerja yang lain & 0,712 & Valid \\
\hline
\end{tabular}

\section{Uji Reliabilitas}

Uji reliabilitas ini merupakan bentuk uji kualitas data yang menunjukkan stabilitas dan konsistensi dari instrumen untuk mengukur konstruk/variabel. Nilai batas yang diperkenankan untuk menilai atau menguji apakah setiap variabel dapat dipercaya, handal dan akurat dipergunakan formula Alpha Cronbach. Suatu kuisioner dikatakan reliabel atau handal jika jawaban responden atas pernyataan adalah konsisten atau stabil dari waktu ke waktu. Instrumen dinyatakan reliabel apabila nilai alpha cronbanch $\geq 0,60$, jika cronbanch alpha< 0,60 maka dikatakan tidak reliabel.

\section{Tabel 7. Uji Reliabilitas}

\begin{tabular}{ccc}
\hline Variabel & Alpa Cronbach & Keterangan \\
\hline Tingkat Pendidikan & 0,702 & Reliabel \\
\hline Usia & 0,746 & Reliabel \\
\hline Pengalaman Kerja & 0,774 & Reliabel \\
\hline Jenis Kelamin & 0,706 & Reliabel \\
\hline Produktivitas Tenaga Kerja & 0,773 & Reliabel
\end{tabular}

\section{Analisis Regresi Linear Berganda}

\section{Tabel 8. Hasil Uji regresi}

Coefficients ${ }^{a}$

\begin{tabular}{|c|c|c|c|c|c|c|}
\hline \multirow[t]{2}{*}{ Mode } & & \multicolumn{2}{|c|}{ Unstandardized Coefficients } & \multirow{2}{*}{$\begin{array}{c}\begin{array}{c}\text { Standardized } \\
\text { Coefficients }\end{array} \\
\text { Beta }\end{array}$} & \multirow[t]{2}{*}{$\mathrm{t}$} & \multirow[t]{2}{*}{ Sig. } \\
\hline & & $B$ & Std. Error & & & \\
\hline \multirow{5}{*}{1} & (Constant) & -.956 & 1.359 & & -.704 & .483 \\
\hline & Tingkat Pendidikan & .268 & .131 & .247 & 2.038 & .044 \\
\hline & Usia & .304 & .130 & .268 & 2.331 & .022 \\
\hline & Pengalaman Kerja & .271 & .127 & .225 & 2.131 & .036 \\
\hline & Jenis Kelamin & .231 & .105 & .178 & 2.192 & .031 \\
\hline
\end{tabular}

a. Dependent Variable: Produktivitas Tenaga Kerja 
Berdasarkan hasil uji t untuk variabel tingkat pendidikan (X1) didapatkan nilai thitung sebesar 2,038 dengan nilai signifikansi 0,044 . Selanjutnya nilai ttabel sebagaimana yang sesuai dengan tabel statistik didapatkan sebesar 1,984. Jika dibandingkan antara thitung dengan ttabel, maka thitung $>t_{\text {tabel }}(2,038>1,984)$. Adapun nilai signifikansi 0,044 lebih kecil dari 0,05 . Hasil pengujian ini menunjukkan bahwa tingkat pendidikan berpengaruh signifikan terhadap produktivitas tenaga kerja. Sehingga dapat disimpulkan bahwa hipotesis pertama ( $\mathrm{H} 1)$ diterima.

Berdasarkan hasil uji t untuk variabel usia (X2) didapatkan nilai thitung sebesar 2,331 dengan nilai signifikansi 0,022 . Selanjutnya nilai tabel sebagaimana yang sesuai dengan tabel statistik didapatkan sebesar 1,984. Jika dibandingkan antara thitung dengan $t_{\text {tabel, }}$ maka $t_{\text {hitung }}>t_{\text {tabel }}(2,331>1,984)$. Adapun nilai signifikansi 0,022 lebih kecil dari 0,05. Hasil pengujian ini menunjukkan bahwa usia berpengaruh signifikan terhadap produktivitas tenaga kerja. Sehingga dapat disimpulkan bahwa hipotesis kedua (H2) diterima.

Berdasarkan hasil uji t untuk variabel pengalaman kerja (X3) didapatkan nilai thitungsebesar 2,131 dengan nilai signifikansi 0,036. Selanjutnya nilai tabel sebagaimana yang sesuai dengan tabel statistik didapatkan sebesar 1,984. Jika dibandingkan antara thitung dengan tabel, maka thitung $>$ tabel $(2,131>1,984)$. Adapun nilai signifikansi 0,036 lebih kecil dari 0,05. Hasil pengujian ini menunjukkan bahwa pengalaman kerja berpengaruh signifikan terhadap produktivitas tenaga kerja. Sehingga dapat disimpulkan bahwa hipotesis ketiga $(\mathrm{H} 3)$ diterima.

Berdasarkan hasil uji t untuk variabel jenis kelamin (X4) didapatkan nilai thitung dari sebesar 2,192 dengan nilai signifikansi 0,031. Selanjutnya nilai tabel sebagaimana yang sesuai dengan tabel statistik didapatkan sebesar 1,984. Jika dibandingkan antara thitung dengan tabel, maka thitung > tabel $(2,192>1,984)$. Adapun nilai signifikansi 0,031 lebih kecil dari 0,05 . Hasil pengujian ini menunjukkan bahwa jenis kelamin berpengaruh signifikan terhadap produktivitas tenaga kerja. Sehingga dapat disimpulkan bahwa hipotesis keempat $(\mathrm{H} 4)$ diterima.

Berdasarkan hasil uji $\mathrm{F}$ di atas diperoleh nilai $F_{\text {hitung }}$ sebesar 51,262 dengan nilai signifikansi 0,000. Jika dibandingkan dengan nilain $F_{\text {tabel }}$ yaitu sebesar 2,47, maka $F_{\text {hitung }}>$ $F_{\text {tabel }}(51,262>2,47)$. Hasil pengujian ini menunjukkan bahwa tingkat pendidikan, usia, pengalaman kerja, dan jenis kelamin secara bersama-sama berpengaruh signifikan terhadap produktivitas tenaga kerja. 


\section{E. SIMPULAN DAN SARAN}

\section{Simpulan}

Adapun beberapa kesimpulan yang dapat ditarik dari hasil penelitian ini, antara lain sebagai berikut:

a. Secara parsial, tingkat pendidikan, usia, pengalaman kerja dan jenis kelamin mempunyai pengaruh signifikan terhadap produktivitas tenaga kerja industri kecil Kota Palopo.

b. Secara simultan, keempat variabel $X$ (tingkat pendidikan, usia, pengalaman kerja, dan jenis kelamin) secara bersama-sama berpengaruh signifikan terhadap produktivitas tenaga kerja industri kecil Kota Palopo.

c. Variabel yang memiliki pengaruh dominan terhadap produktivitas tenaga kerja yaitu variabel usia.

\section{Saran}

Berdasarkan kesimpulan di atas, dapat dihasilkan beberapa saran anatara lain sebagai berikut:

a. Para pelaku industri kecil dapat meningkatkan produktivitas tenaga kerjanya dengan berbagai upaya antara lain: pertama, meningkatkan pengetahuan dan pengalaman kerja melalui Pendidikan baik formal maupun informal bagi tenaga kerja. Kedua, memperhatikan usia produktif dari tenaga kerja sehingga produktivitas kerja dapat tercapai dengan optimal. Ketiga, menggunakan tenaga kerja yang sudah memiliki pengalaman kerja sehingga lebih terampil dan dapat mengurangi kesalahan dalam menyelesaikan pekerjaan.

b. Diharapkan adanya upaya yang dilakukan pemerintah dalam rangka melakukan pembinaan terhadap industri kecil, antara lain dengan memberikan pendidikan dan pelatihan bagi tenaga kerja industri kecil. Hal ini sangat penting untuk menambah pengetahuan dan wawasan dalam meningkatkan produktifitas tenaga kerja.

c. Diharapkan dapat menjadi bahan pengembangan kajian ilmu manajemen sumber daya manusia terkhusus mengenai produktivitas tenaga kerja dalam rangka upaya peningkatan produksi pada industri kecil.

\section{DAFTAR PUSTAKA}

Amron dan Taufiq Imran. 2009. Analisis Faktor-Faktor yang Berpengaruh Terhadap Produktivitas Tenaga kerja Outlet Telekomunikasi Seluler Kota Makassar. Jurnal Sekolah Tinggi Ilmu Ekonomi Nobel Indonesia.

Hasanah, Erni Ummi dan Widowati, Puri. 2011. Analisis Produktivitas Tenaga Kerja pada Industri Rumah Tangga Krecek di Kelurahan Segoroyoso. Efektif Jurnal Bisnis dan Ekonomi, vol.2, no.2, hal. 169-182. 
Korawijayanti, Lardin dan Listyani, Tyas. 2009. Pengaruh Perkembangan Usaha Kecil Menengah Terhadap Keberdayaan Perempuan di Jawa Tengah, Jurnal Ragam, vol. 9, no. 2, hal. 166-182.

Ngantindriatun dan Ikasari, Hertiana. 2011. Efisiensi Produksi Industri Skala Kecil Batik Semarang: Pendekatan Fungsi Produksi Frontier Stokastik. Jurnal Manajemen Teori dan Terapan, no.1, tahun 4, hal. 28-36.

Rahmana, Arif. 2009. Peranan Teknologi Informasi dalam Peningkatan Daya Saing Usaha Kecil Menengah. Seminar Nasional Aplikasi Teknologi Informasi Yogyakarta.

Sitanggang, Ignatia Rohana dan Nachrowi, Djalal. 2006. Pengaruh Struktur Ekonomi Pada Penyerapan Tenaga Kerja Sektoral: Analisis Model Demometrik di 30 Provinsi Pada 9 Sektor di Indonesia. Jurnal Ekonomi danPembangunan Indonesia, vol.5, no.1, hal 103-133.

Sulaeman, Ardika. 2014. Pengaruh Upah dan Pengalaman Kerja terhadap Produktivitas Karyawan Kerajinan Ukiran Kabupaten Subang. Jurnal Trikonomika, vol. 13, no.1, hal. 91-100.

Sugiyono. 2009. Metode Penelitian Kuantitatif, Kualitatif, dan R\&D. CV. Alfabeta, Bandung.

Suyono, Bambang dan Hermawan, Hery. 2013. Analisis Faktor-faktor yang Mempengaruhi Produktivitas Tenaga Kerja pada Industri Kerajinan Kulit di Kabupaten Magetan. Jurnal Ekomaks, vol.2, no.2.

Utami, Annisa Wanda dkk. 2015. Analisis Produktivitas Tenaga Kerja pada Usaha Domba Analysis Farm Worker Productivity in Sheep Farm. Fakultas Peternakan Universitas Padjajaran. Artikel tidak terpublikasi.

Wartana, I Made Hedy. 2011. Faktor-faktor yang Mempengaruhi Produktivitas Kerja Karyawan pada Como Shambala Estate at Begawan Giri Ubud Bali. Jurnal Perhotelan dan Pariwisata, vol.1, no.1, hal. 14. 
Kelola: Journal of Islamic Education Management Vol.2, No.2 Oktober 2017, Hal 187 -198

ISSN : $2548-4052$

@2017 Manajemen Pendidikan Islam: manajemenmpi@gmail.com 
Kelola: Journal of Islamic Education Management

Vol.2, No.2 Oktober 2017, Hal $187-198$

ISSN : 2548 - 4052

@2017 Manajemen Pendidikan Islam: manajemenmpi@gmail.com 
